\title{
ВСЕСОЮЗНОЕ НАУЧНО-ТЕХНИЧЕСКОЕ СОВЕЩАНИЕ ПО ПРОМЫШЛЕННОМУ ПРИМЕНЕНИЮ ТОКОВ ВЫСОКОИ ЧАСТОТЫ
}

Промышленные методы термообработки мета.т.тов и непроводниковых материалов с применением токов высокой и промышленной частоты получили весьма широкое применение. Мощности устансвок высокочастотного нагрева на предприятня крупнейших промышленных центров Советского Союза достигают тысячи киловатт, Іоходя в отдельных случаях до 10-12 тыс. $k 8 m$.

Важность вопросов и объем работ по применени тожов высокой частоты в промыш-ёности вьзј:вают острую необходимость з б5џене опытом н информацией.

С 1951 г. в . Іеннираде дериодически проводятся всесогзаЕе эоэсеречцин и совешания, посвященные промьіленному применению тохов высоког эастоты.

Состоявшееся в пернод 12-16 чоября 1957 г. Всесоюзное совешание го прс. мыш.тенному применению токов взісовой частоты было органнзовано Ко:гетсм промышленного применения токов высокой частоты нм. проф. В. П. Во.тогдна Ленинградского областного прав.леня НТО Машпром и секцией электротермнческих установок Ленинградского об.тастного правления НТО Энергопром.

В работе совещания приняли јчастие свыше 600 делегатов от высших учебных заведений, научно-исследовательских институтов, конструкторских бюро и промышленных предприятий, в том числе представители научно-технической общественности Германской Демократической Республики и Румынской Народной Республикн.

Основная работа совещания проходила в четырех секциях: оборудования-руководитель д. т. н. проф. А. В. Донской (ЛПИ им. М. И. Калинина), технологии индукционного нагрева - руководитель к. т. н. доц. А. Е. Слухоцкий (ЛЭТИ нм. В. И. Ульянова (Ленина), нагрева непроводниковых материалов - руководитель ст. преподаватель В. В. Вологдин (ЛЭТИ), металловедения - руководнтель к. т. н. Г. Ф. Головин (НИИ ТВЧ им. проф. В. П. Вологдина).

Доклады, касающиеся общих вопросов, были вынесены на пленарные заседания: - Новое в области промышленного прнменения токов высокой частоты (M. А. Спицын, НИИ ТВЧ), «Бестигельная плавка при индукционном нагреве (А. А. Фогель, лаборатория высокочастотной электротермии АН СССР), «Электрические свойства промышленных материалов при высоких частотах и особенности их измерения (А. В. Нетушил и В. Н. Кудин, МЭИ), «Понижение прокаливаемости как средство достижения контурной закалки шестерен (К. 3. Шепеляжовский, ЗИЛ, Москва), «Достижения и перспективы применения индукционного нагрева в Румынской Народной Респуб. лике» (Сечеляну, Румынская Народная Республика) и др.

Всего на совещанин было заслушано 82 доклада и сообщения.

Среди докладов и сообщений, изложенных на секциях, большой интерес и широкий обмен мнениями вызвали следующие:

По секции оборудования - «Ионные преобразователи частоты для электротермических установок" (А. В. Донской, А. Н. Борок, Г. В. Ивенский - ЛПИ), «Инвенторы на электронных лампах» (А. Е. Слухоцкий, ЛЭТИ), «Новые высокочастотные трансформаторы» (Л. А. Тир, ОКБ треста «Электропечь», Москва), «Автоматическая стабилизация нагрева в установках с ламповыми генераторами» (А. Е. Слухоцкий - ЛЭТИ, А. В. Бамунэр, НИИ ТВЧ), «Применение ферритов в аппаратуре для индукционног нагрева» (Э. Тритмахер, Германская Демократнческая Республика).

По секции технологии индуктивного нагрева - «Сварка металлов при высокочастотном нагреве» (Н. П. Глуханов, ННИ ТВЧ', «Нндукционная поверхност. ная зака.тка изделий из чугуна с шаро. вндным графитом» (К. Н. Шаганова н А. Д. Свершников, Горьковский автомоби.тьный завод), «Энергетические соот. ношения при индукционной плавке кремния» Ю. Э. Недзвецкий, В. И. Добровольская, Д. Г. Ратников - НИИ ТВЧ), «Применение индукционного нагрева токов ВЧ с целью повышения прочности стыко-сварных труб нефтяного сортамента» (3. Г. Напетваридзе).

По секции нагрева непроводниковых материалов - «Применение сантиметровых волн для автоматического контроля влажности» (Ю. Э. Недзвецкий, НИИ ТВЧ), «Применение высокочастотного нагрева в резиновой промышленности» (Х. Е. Малкина, Москва), «Аппаратура непрерывного действия для термообра. ботки диэлектрнческих материалов с применением токов высокой частоты» (И. П. Сахаров, Москва).

По секцин металловедения - «Остаточные напряжения при поверхностной закалке цилиндрических изделий» (Г. Ф. Головин, НИИ ТВЧ), «Газовая цементация при индукционном нагреве» (П. А. Ланкин, ЗИЛ), «Некоторые свойства закаленных токами ВЧ деталей и поведение их в эксплуатация (И. Н. Горбульский, ЧТЗ).

В результате обмена мнениями и дискуссий по важнейшим вопросам, затронутым в докладах и выступлениях, совещание вынесло ряд решений, направленных на дальнейшее развитие промышленного применения токов высокой частоты.

Особенно существенными следует считать планирование мероприятий по пересмотру номенклатуры и повышению ка- 
чества аппаратуры и приборов для высокочастотного нагрева, дальнейшему развитию и координации научно-исследовательской работы, под отовке кадров средне-технического персонала для обслуживания установок, усилению пропаганды высокочастотной электротермии путем увеличения выпуска научно-технической, справочной и периодической литературы.

Совещание, несомненно, явилось важным положительным фактором в деле дальнейшего развития высокочастотной: техники.

Поступила в редакцию 3 I.JL I958 r.

Доц. А. С. Васильев 